\title{
THE OPERATIONAL ASPECTS OF OPEN AND DISTANCE LEARNING AND ITS QUALITY ASSURANCE SYSTEM IN UNIVERSITAS TERBUKA
}

\author{
Aminudin Zuhairi \\ Universitas Terbuka \\ e-mail: aminz@ecampus.ut.ac.id
}

\begin{abstract}
ABSTRAK
Universitas Terbuka (UT) telah berfungsi sejak 1984 untuk memperluas kesempatan belajar bagi seluruh warga negara Indonesia dari berbagai lapisan guna menempuh pendidikan tinggi berkualitas. Makalah ini menyajikan aspek operasional pendidikan terbuka dan jarak jauh beserta sistem penjaminan kualitas UT. Deskripsi dan analisis tentang UT disampaikan dalam hal sistem pembelajaran, asesmen pembelajaran, dan sistem pendukung layanan operasional. Beragam layanan pendukung pembelajaran diberikan sesuai kebutuhan mahasiswa meliputi pembelajaran jarak jauh dengan tutorial online, pembelajaran jarak jauh blended dengan tutorial tatap muka dan online, pembelajaran jarak jauh dengan semua matakuliah didukung tutorial tatap muka, dan pembelajaran fully online. Sistem penjaminan kualitas UT meliputi pengembangan budaya kerja berkualitas sebagai tanggung jawab bersama, fokus pada pencegahan, dan pengembangan mekanisme asesmen kualitas secara internal dan eksternal. UT telah mengadopsi Asian Association of Open Universities (AAOU) Quality Assurance Framework sejak tahun 2001. Asesmen dan review kualitas secara eksternal telah dilakukan melalui sertifikasi ISO 9001 dan ISO 27001, akreditasi Program Studi dan Institusi oleh Badan Akreditasi Nasional Perguruan Tinggi (BAN-PT), dan review kualitas oleh International Council for Open and Distance Education (ICDE). Arah ke depan UT sebagaimana dinyatakan oleh Menteri Riset, Teknologi, dan Pendidikan Tinggi 2014-2015 adalah tantangan UT sebagai pelopor cyber university di Indonesia serta menyediakan matakuliah online bagi mahasiswa dari perguruan tinggi di Indonesia lain agar memiliki pengalaman pembelajaran online.
\end{abstract}

Kata kunci: open and distance learning, open university, operational system, quality assurance

\begin{abstract}
Universitas Terbuka (UT) has been functioning since 1984 to widen opportunities for the citizens of Indonesia from all geographical, social and economic backgrounds to have access to quality higher education. This paper presents the UT operational aspects of open and distance learning and its quality assurance system. The description and analysis of UT is presented in terms of teaching and learning system, assessment of student learning, and operational support system. The UT modes of learning support to students are provided based on the students' needs to include distance learning with online tutorials, blended distance learning with face-to-face and online tutorials, distance learning with all courses supported by face-to-face tutorials, and fully online learning courses. Quality assurance is discussed in terms of the development of quality work culture as shared responsibility, focus on prevention, and the establishment of mechanism for internal and external assessment. UT has adopted the Asian Association of Open Universities (AAOU) Quality Assurance
\end{abstract}


Framework since 2001. External quality assessment includes certification for ISO 9001 and ISO 27001, Study Program and Institution accreditations by the National Board of Higher Education Accreditation (BAN-PT), and quality reviews by the International Council for Open and Distance Education (ICDE). Future directions of UT as stated by the former Minister of Research, Technology, and Higher Education was to be pioneer in cyber university and to provide online courses for students from other universities in Indonesia.

Keywords: open and distance learning, open university, operational system, quality assurance

\section{INTRODUCTION TO HIGHER EDUCATION IN INDONESIA}

The right to education for all citizens is stated in the Constitution 1945 of the Republic of Indonesia Chapter XIII Article 31 (1) Every citizen has the right to education; and (2) The Government organizes and governs a national education system regulated by the Law. The Education Law 20/2003 Article 5 further state that every citizen has the right to quality education, special needs education, special educational services in remote location and cultural environment, special education for the gifted, and pursue lifelong learning. These Laws are to be implemented by the relevant Ministries at national level and District Offices at district levels in charge of education matters.

The higher education system in Indonesia has continuously expanded and evolved to meet the changing needs of the society and the world of work. Originating from religious teachings in the past, the formal higher education institutions of Indonesia started during the end of the $18^{\text {th }}$ century as an elitist higher education system established by the Dutch colonial ruler for the Dutch interests (Logli, 2015, Logli 2016; Pannen, 2018). The post-independence higher education system of Indonesia has since continued to flourish and transform themselves adapting to the needs of the society and new technology.

Table 1. Indicators of Higher Education System in Indonesia

\begin{tabular}{ll}
\hline Indicators & Numbers \\
\hline Population & 266 million people \\
20-24 years of age & 21 million people \\
Higher education institutions & 4,612 \\
Universities public and private & 3,250 \\
Open university & 1 \\
Study Programs & 27,241 \\
Students in higher education & 8.3 million students \\
National participation in HE (18-24) & $32.5 \%$ in 2018 targeted $50 \%$ in 2040 \\
\hline
\end{tabular}

Source: Ahmad, 2018; Pannen, 2018

During the post-independence era, the 1 st Islamic university, Universitas Islam Indonesia, was established 1in 1945, and the $1^{\text {st }}$ national university, Universitas Gajah Mada, was founded in 1949, both of which in the city of Yogyakarta on the island of Java (Logli, 2016; Pannen, 2018; UGM, 2020). The Indonesian higher education system has since then developed to become an inclusive and diversified structure, including public and private institutions as well as national and religious 
based institutions. Several types of higher education institutions can be found, including community academy, academy, polytechnic, college, institute, university, and autonomous state university. These higher education institutions offer study programs including vocational (diploma) and academic (bachelor, master, doctoral) programs in accordance to the Law and government regulations (Ahmad, 2018; Pannen, 2018). Table 1 shows indicators of higher education system, institutions, and students in Indonesia.

\section{Universitas Terbuka as part of the Indonesian higher education system}

The open university system has been established following the success of the pioneering foundation of the United Kingdom Open University (UKOU) in 1969. Lord Geoffrey Crowther, the first chancellor of the UKOU, proclaimed its radical purpose of being "open as to people, open as to places, open as to methods and open as to ideas" (Crowther, 1969 in Daniel, 2019, pp. 196). Since then governments in the world have established open universities in their respective countries modelled on the UKOU system. Many open universities particularly in Asia have flourished to become mega universities or very large open universities, each of which with enrolments of over 100,000 students. The open university system has been viewed as the effective solution to address higher education needs of the citizens using printed learning materials and broadcast initially, and now using new technology that allows greater flexibility through digital learning and online interaction. Irrespective of where they have been established, open universities share common ideals and philosophies of openness, access, equality, and quality. For UT specifically, it has adopted the principles of quality, integrity, innovation, accessibility, relevance, and accountability to ensure student learning process, and its output and outcome (UT, 2017). Figure 1 indicates the foundation philosophies of open universities and UT principles to provide student learning process with effective output and outcome.

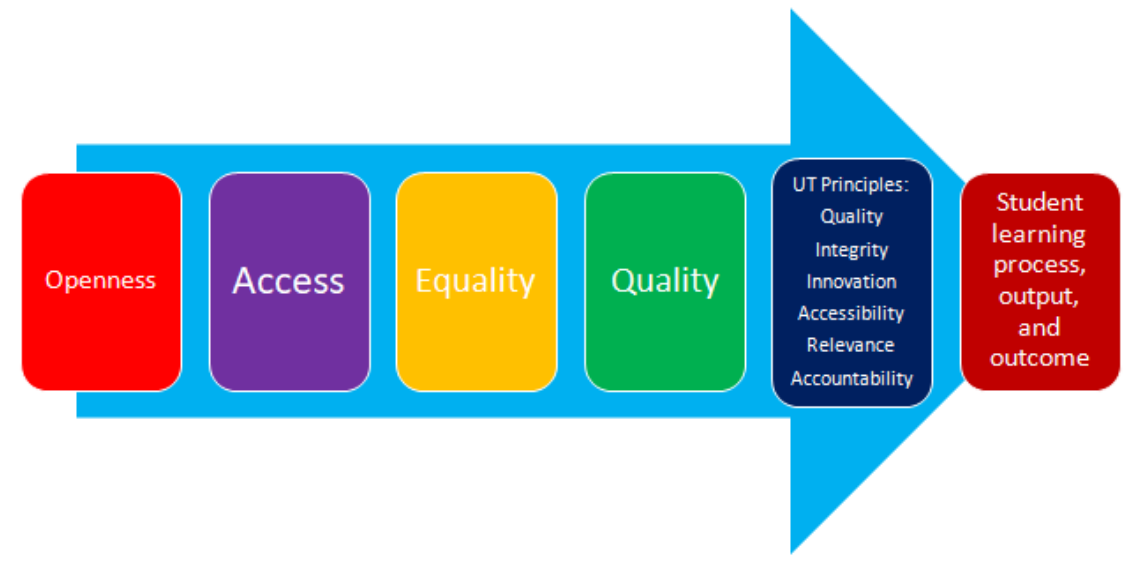

Figure 1. The foundation philosophies of open universities and UT principles

Established as an open university on the $4^{\text {th }}$ of September 1984, UT has clear policies of open access to quality higher education for high school graduates, adults, teachers, and everybody else. The terms open implies that it is open in terms of admission for high school graduates, mode of learning support, choice of media, duration of study, and flexibility in studying. The tag line "making higher education open to all" sums up UT policies as an open university welcoming everybody. During its life as a higher education institution, UT has attempted to bridge the distance with its 
students through open and flexible learning methods. In line with the development technology, UT continues to be in the process of transformation from traditional open and distance teaching university into integrating online learning system to become a cyber university able to meet the changing needs of its stakeholders and society.

Founded upon the Presidential Decision No. 41/1984 as its legal platform, UT has been designed to serve students living in all areas throughout the country and those living outside the country using distance learning system. The national language, Bahasa Indonesia, has been used as the language of instruction. Everybody with at least a high school certificate may be admitted through its open admission system as UT students for its undergraduate programs, although the postgraduate programs apply certain selection criteria for admission. Currently UT has 36 academic programs within 4 Faculties, namely Science and Technology; Teacher Training and Education; Economics; and Law, Social and Political Sciences. The four Faculties offer a total of 1,257 courses for 37 Bachelor, 3 Undergraduate Diploma, 6 Master, 1 Post-Graduate Diploma, and 2 Doctoral programs. To serve its students, UT has a Head Office in Tangerang Selatan, with 39 Regional Offices in each of the Provinces, and an Overseas Student Center to provide services for students studying in 40 countries. Figure 2 maps the UT Regional Offices and scope of services nation-wide and globally.

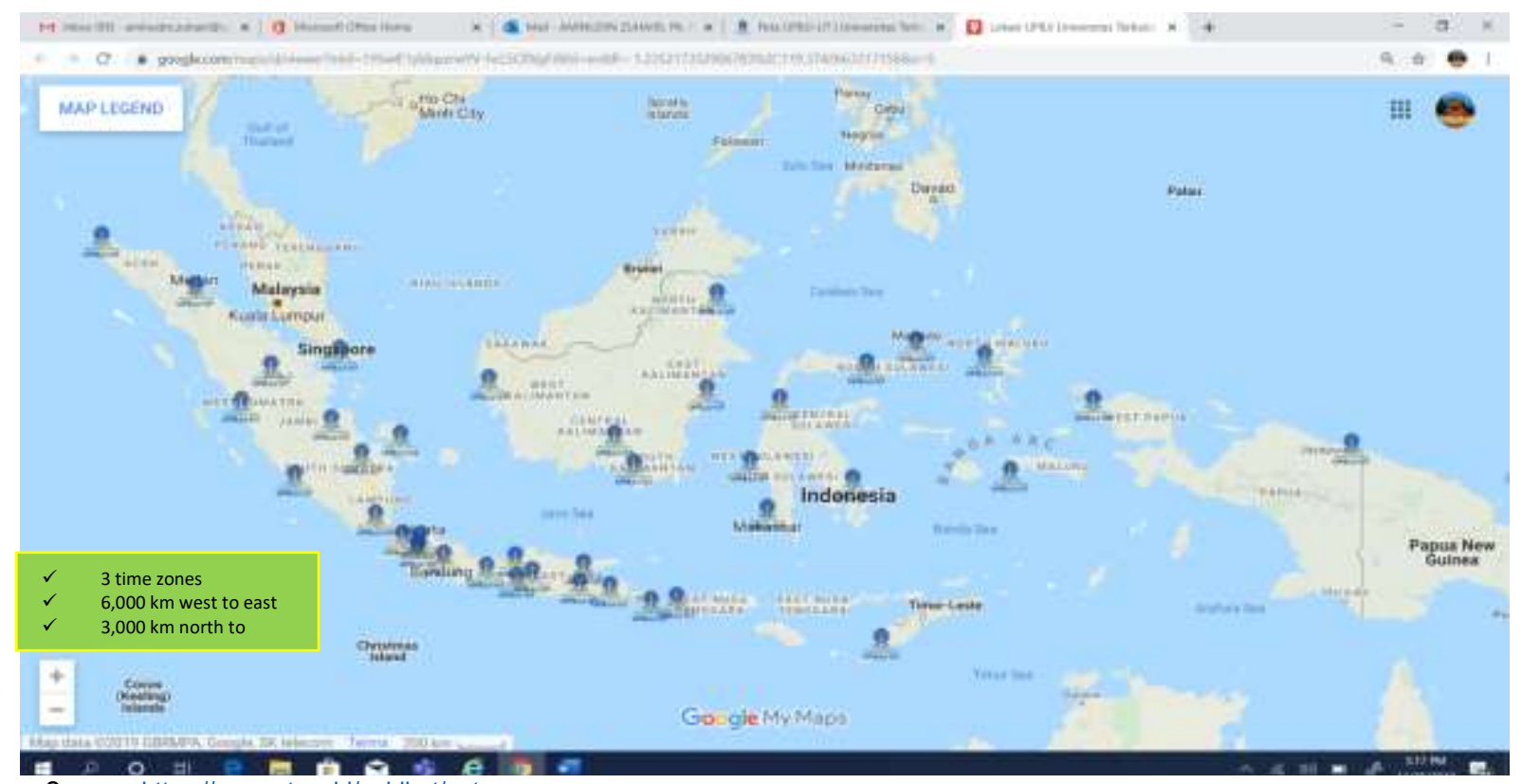

Source: https://www.ut.ac.id/upbji-ut/peta

Figure 2. UT regional offices and scope of services nation-wide and globally

As a state-owned public service organization, UT performance indicators are decided and then measured jointly by the Ministry of Finance and the Ministry of Education and Culture, or previously Ministry of Research, Technology, and Higher Education. In terms of quality management, UT has employed a quality assurance system, involving mechanisms for internal and external assessments. Since 2001, the Asian Association of Open Universities (AAOU) Quality Assurance Framework has been adopted for implementation in UT. External assessment has been conducted to 
ensure consistency and provide feedback for continuous improvement through ISO certification, accreditation by the National Board for Higher Education Accreditation, and quality reviews by the International Council for Open and Distance Education (ICDE). Table 2 shows UT institutional indicators.

Table 2. Indicators of Universitas Terbuka

\begin{tabular}{ll}
\hline Indicators & What UT provides \\
\hline Year established & 1984,35 years \\
Legal foundation & Presidential Decision \\
Area served & National and global \\
Language of instruction & Bahasa Indonesia, English (for English Program) \\
Client & Indonesians \& everybody \\
Faculty & 4 \\
Study Programs & 48 \\
Post-graduate programs & 7 Master +2 Doctoral \\
Courses & 1,257 \\
Examination sites & 802 \\
Courses with online exam & 856 \\
Head Office & Tangerang Selatan \\
Regional offices & $39+1$ Overseas Student Center \\
Performance indicators & Set by Ministry of Finance \& Ministry of STHE \\
Quality assurance system & Internal QA, and External by ISO, ICDE, BAN-PT \\
\hline Source: UT, 2019a &
\end{tabular}

In 2018, UT enrolled 302,484 students, with 193,783 students attending face-to-face tutorials in 331 locations nearby students' residences, employing 11,306 face-to-face tutors. There were 85,427 students enrolling in online tutorials, contributing a total of 489,600 student/courses in a semester.

Table 3. Indicators of UT students

\begin{tabular}{ll}
\hline Indicators & UT in numbers \\
\hline Students & 302,484 \\
Students in face-to-face tutorials & 193,783 \\
Students in online tutorials & 85,427 students \\
Students/courses in online tutorials & 489,600 student/courses \\
Students taking online exam & 49,696 \\
Students unemployed & $25,572(8.45 \%)$ \\
Students female & $199,651(66 \%)$ \\
Convocation in Head Office & 6 times per year \\
Convocation in Regional Office & $2-4$ times a year \\
Graduating in 2018/19 & 56,528 \\
Alumni total in 2018/19 & $1,726,515$ \\
Alumni Diploma, Bachelor, Master & $934,703(54.14 \%), 788,338(45.66 \%), 3,474(.20 \%)$ \\
\hline Source: UT, 2019a
\end{tabular}


There were 49,696 students taking online examination in 2018/19.1. The statistical data indicated that the number of students unemployed were $25,572(8.45 \%)$, and there were more female students totaling 199,651 (66\%). Convocations in Head Office were held 6 times per year, and Convocations in Regional Offices were 2-4 times a year. Every year about 50,000 students graduate from UT, making the number of alumni totaling 1,726,515, including Diploma 934,703 (54.14\%), Bachelor $788,338(45.66 \%)$, and Master 3,474 (.20\%). UT students participate in activities nationally and internationally, relevant to the development of soft skills, hard skills, and in various competitions. Table 3 presents indicators of UT students.

\section{Teaching and learning}

UT employs instructional strategies that allow flexibility on the parts of the students. As an open university, UT has continued to transform itself from the traditional open university to become a modern cyber university, accommodating the different needs of students and the interests of stakeholders. Blended online learning is employed to allow for easy access, flexibility, and choices that facilitate student learning. Once students enroll in UT courses, they are provided with two-day new student orientation and development of distance learning skills. Self-instructional learning materials for independent and self-directed learning are provided in two formats, namely the digital format sent to student emails and the printed learning materials delivered to students' addresses.

Learning support services are provided to students as choices in different modes through online tutorials, face-to-face tutorials, supervised practice and practicum, depending on the students' conditions and the requirements of the course. Three assignments are requested for each course to be submitted by students participating in online and face-to-face tutorials contributing to the final grade for the course. Practical experiences of the students are developed using practicum guidelines, dry lab, and wet lab in partnerships with other institutions. Students with difficulties are supported through access to services such as remediation, intervention, academic counselling, learning clinics for students with difficulties conducted both online and face-to-face depending on the needs of the students. Thesis supervision for master and doctoral students are provided in collaboration with senior academic of campus-based universities. UT practices the approach of sharing its learning resources through online access to digital library, dry lab, self-exercise, OERs through video, UTRadio, UT-TV, and Contact Center, some of which are available to the public. Table 4 presents UT indicators of teaching and learning.

Table 4. Indicators of teaching and learning at Universitas Terbuka

\begin{tabular}{ll}
\hline Indicators & What UT provides \\
\hline Admission of new students & All year long \\
Induction of new students & Orientation \& ODL skills development \\
Course registration & Every semester \\
Loose courses & Yes \\
Lifelong learning courses & Yes \\
MOOCs & Yes \\
OERs & Yes \\
Learning materials format & Printed and digital \\
Digital library & Yes \\
Face-to-face tutorials & 8 sessions in weekends \\
\hline
\end{tabular}


Table 4. advanced

\begin{tabular}{ll}
\hline Indicators & What UT provides \\
\hline Online tutorials & 8 sessions for 8 weeks, tutor initiations \\
Practice & Yes \\
Practicum & Yes \\
Virtual/online/dry lab & Yes \\
Online courses/tutorials & 1,170 \\
Online learning platform & Moodle 3.5 \\
Students' activities & Yes, soft skills, hard skills, competitions \\
\hline
\end{tabular}

Source: UT, 2019a

\section{Operational support system}

UT operations system in semester cycle begins with admission of new students going all the way through course registration, provision of learning materials, learning support, and assessment at the end of the semester. This cycle continues for several semesters for different groups of students, depending on the program and level, usually 8 semesters for the bachelor program, 4 semesters for the master program, and 6 semesters for the doctoral program, and eventually leads to the graduation of the students at the end of the program. Table 5 shows indicators of human resources in numbers used to provide academic, administrative and support services to UT distance students.

Table 5. Indicators of human resources used

\begin{tabular}{ll}
\hline Indicators & Human resources in numbers \\
\hline Academic staff & 635 \\
Administrative staff & 1,235 \\
Staff in Head Office & 901 \\
Staff in Regional Office & 1,361 \\
Staff total & 2,262 \\
Face-to-face tutors & $11,306(1: 30$ ratio $)$ \\
\hline Source: UT, 2019a
\end{tabular}

Admission of new students. Principally UT admits students with high school certificates to its undergraduate programs without selection all year long. The post-graduate programs employ certain criteria and selection for admission. Students may apply for admission and submit application documents through one of UT Regional Offices or submit the application documents online. Admitted students will be provided with access to UT online learning management system and the Microsoft Office 365 software. New students are invited to attend two-day sessions on orientation about distance learning to new students and the development of distance learning skills workshop in certain locations accessible form their residences.

Course registration. Course registration can be done by students online or through the Regional Office during the beginning of every semester. Different fee structures apply depending on the modes of learning support services and Study Programs that students choose. Students have flexibility in making choices of study loads, number of courses, media, and modes of learning support services based on their personal circumstances and conditions. For example, it is up to individual students to opt for pre-packaged courses designed to finish in 8 semesters for a bachelor's degree, 
or individual un-packaged courses that may take them longer or even sooner to finish an undergraduate program.

Learning materials. Once the students register for courses, printed learning materials for the courses are delivered to students' addresses and the digital format of the learning materials are emailed to students individually. Access to UT Digital Library is granted to all registered students. Access to OERs, iTV, iRadio is open to students and the public. These learning and enrichment materials are expected to facilitate students' independent learning and group learning activities during the face-to-face and online tutorials sessions as well as during their own learning activities.

Learning support. Learning support services are provided to students in various forms, including online and face-to-face tutorials, supervised practice, and supervised practicum through dry lab, wet lab, or using independent practicum kits. Students have access to enrichment of learning experience through OERs. Students are requested to submit assignments, practice and practicum reports for feedback and assessment by tutors and supervisors. Interaction with the tutor and peers take place during the face-to-face and online tutorial sessions. Students may establish study groups to enhance their understanding of the learning materials. Online discussion forums are provided to encourage peer learning among students. Post-graduate students attend thesis seminar and supervision sessions conducted face-to-face or mediated via web-conferencing. Further enquiries and complaints are delivered by students through Contact Centre in the Head Office or relevant Regional Offices.

Examination. Examination is conducted at the end of the semester using paper-based examination. Online examination may be provided as additional service upon request of the students through registering for the online examination. Students may take or retake examination online in designated locations to suit their individual schedules. These semester examinations are in the forms of essay and multiple-choice tests. Some courses require the submission of practice and practicum reports following the guidelines of the course. Some courses are assessed using oral and portfolio assessment. Undergraduate students are required to take a written comprehensive examination towards the end of the program. Thesis supervision and examination are conducted face-to-face or mediated via web conferencing for the post-graduate students at the end of the program.

Graduation and convocation. Every year UT holds 6 convocations in Head Office, and 2 to 4 Convocations in each of the Regional Offices. The top 2,500 graduates are invited to the Head Office for the convocation, and the remaining graduates are presented with the certificates in the Regional Office. Alumni network has been established to facilitate participation of alumni in supporting UT academic as well as other activities.

\section{Modes of learning support}

The modes of learning support for the students to choose from can be generally categorized into four types, namely distance learning with online tutorials, blended distance learning supported with online and tutorials, and distance learning fully supported with face-to-face tutorials, and fully online learning. Tuition fees charged to the students depend on the kinds of modes of learning support services provided to the students. Irrespective of the modes of learning support, all students are provided with the following support services.

$\checkmark$ Printed learning materials delivered to students' locations.

$\checkmark \quad$ Digital learning materials emailed to students, downloadable into 2 types of gadgets: Android or IOS, and notebook or desktop.

$\checkmark \quad$ Online tutorials for all courses. 
$\checkmark \quad$ Paper-based semester exam in more than 800 cities within the country, and in more than 40 overseas country locations.

$\checkmark \quad$ Other services with additional fees or upon request by the students, e.g., face-to-face tutorials, online examination (UT, 2019).

Students may select the modes of learning support to suit their needs and circumstances. Fees are charged based on the kinds of learning support that students choose, ranging from the basic mode of learning support using "distance learning with online tutorials" as the lowest in fees up to the "distance learning with all courses supported by face-to-face tutorials" as the highest fees. The fees for the "fully online learning courses" lie in the middle of the range. Table 6 indicates the variety of modes for support to student learning.

Table 6. Modes of learning support to UT students

\begin{tabular}{|c|c|}
\hline Modes of learning support & Services provided \\
\hline Distance learning with online & $\checkmark \quad$ Independent and self-directed learning materials \\
\hline tutorials & $\begin{array}{l}\checkmark \text { In package of 6-7 courses, } 18 \text { to } 21 \text { credits per semester, or } \\
\text { Minimum } 1 \text { course, } 2-4 \text { credits, and maximum 7-8 courses, } 24 \\
\text { credits. }\end{array}$ \\
\hline $\begin{array}{l}\text { Blended distance learning } \\
\text { with face-to-face and online } \\
\text { tutorials }\end{array}$ & $\begin{array}{l}\checkmark 3 \text { courses provided with face-to-face tutorials } 8 \text { sessions in } \\
\text { weekends } \\
\checkmark \quad \text { Online tutorials for all remaining } 3-4 \text { courses } \\
\checkmark \text { In package of 6-7 courses, } 18 \text { to } 21 \text { credits per semester }\end{array}$ \\
\hline $\begin{array}{l}\text { Distance learning with all } \\
\text { courses supported with face- } \\
\text { to-face tutorials }\end{array}$ & $\begin{array}{l}\checkmark \text { In package of 6-7 courses, } 18 \text { to } 21 \text { credits per semester } \\
\checkmark 1 \text { course only with online tutorials for students to have online } \\
\text { learning experience } \\
\checkmark \quad \text { All 6-7 courses provided with face-to-face tutorials } 8 \text { sessions } \\
\text { in weekends per course }\end{array}$ \\
\hline Fully online learning courses & $\begin{array}{l}\checkmark \text { Online examination for all courses } \\
\checkmark \text { In package of } 6-7 \text { courses, } 18 \text { to } 21 \text { credits per semester }\end{array}$ \\
\hline
\end{tabular}

Source: UT, 2019

Contact and communication support are provided through various means, including through Contact Center in Head Office and Regional Offices. Social media are widely used by students that allow them to make contacts with UT via email, regular mail, twitter, facebook, Instagram, fax, telephone, visit, and these will be addressed by the Contact Center and relevant units. Online forum allows of peer interaction as well as interaction with academic members and tutors. Students have open and free access to online learning support via UT Online page, OER, UT-TV, UT-Radio, and digital library. Study Program contacts can be reached by students through various channels online and mediated, and occasionally physically visiting UT Head Office. Peer group interaction are encouraged during online and face-to-face tutorials or via social media. Interaction with tutors take place mainly during face-to-face or online tutorials. Student may also visit to the Regional Office for academic as well administrative services. Staff visit locations for tutorial, practice, and practicum locations to monitor and supervise academic activities and administrative matters. 


\section{Assessment of student learning}

Student learning are continuously assessed using a variety of assessment methods and instruments. These assessment methods include exercises and formative tests with self-assessment guides in the learning materials. Three assignments, interactivity, and participation in tutorials are designed, contributing $30 \%$ (online) or $50 \%$ (face-to-face) to final grade for the course. At the end of the semester, students are assessed through paper-based semester examination paper-based, while online examination is provided as additional service to provide students with flexibility in terms of time. Final Comprehensive Examination are administered towards the end of the Program. Then scientific paper upload is requested to students before the end of the Program. There is further examination of theses submitted by master and doctoral students. Table 7 shows indicators of UT student learning assessment.

Table 7. Assessment of Student Learning

\begin{tabular}{ll}
\hline Indicators & What UT does \\
\hline Semester exam & Yes \\
Objective test & Yes \\
Face-to-face tutorial assignments (3) & Yes, $50 \%$ contribution \\
Online tutorial assignments (3) & Yes, 30\% contribution \\
Essay test & Yes \\
Paper-based exam & Yes \\
Online exam & Yes \\
Practice exam & Yes \\
Practicum assessment & Yes \\
Portfolio assessment & Yes \\
Comprehensive exam & Yes \\
Thesis exam & Yes \\
\hline Source: UT, 2019a &
\end{tabular}

\section{Quality assurance (QA) system}

UT has since 2001 implemented fundamental steps to establish a systematic quality assurance system in open and distance learning. First, the development of quality work culture as shared responsibilities by all management and staff is fundamental in quality assurance. Second, good quality assurance system focuses on preventive actions and continuous improvement. Third, it is important to establish a quality assurance mechanism involving internal and external assessments coordinated by the Quality Assurance Center. For UT, it started with the establishment of QA System Committee 2001-2003, followed by the foundation of a QA Center since 2003 until today. UT has decided to adopt and implement the Asian Association of Open Universities (AAOU) QA Framework (Belawati and Zuhairi, 2007; Darojat, 2018). Table 8 indicates the components and sub-components of the AAOU QA Framework. 
Table 8. Components of AAOU QA Framework

\begin{tabular}{ll}
\hline Components & Number of sub-components \\
\hline Policy and Planning & 7 \\
Internal Management & 7 \\
Learners and Leaners' Profiles & 11 \\
Infrastructure, Media, and Learning Resources & 3 \\
Learner Assessment and Evaluation & 5 \\
Research and Community Services & 5 \\
Human Resources & 5 \\
Learner Support & 2 \\
Program Design and Curriculum Development & 2 \\
Course Design and Development & 6 \\
Total & 53 \\
\hline
\end{tabular}

Source: http://aaou.upou.edu.ph/quality-assurance-framework/ 27 October 2019

Figure 3 describes UT QA in operational areas, which includes the supply chain system and logistic support for the students, tutors, partners, and ensure the smooth running of academic and administrative services to students. These include core activities covering the operational aspects of registration, learning materials, learner support, and examination.
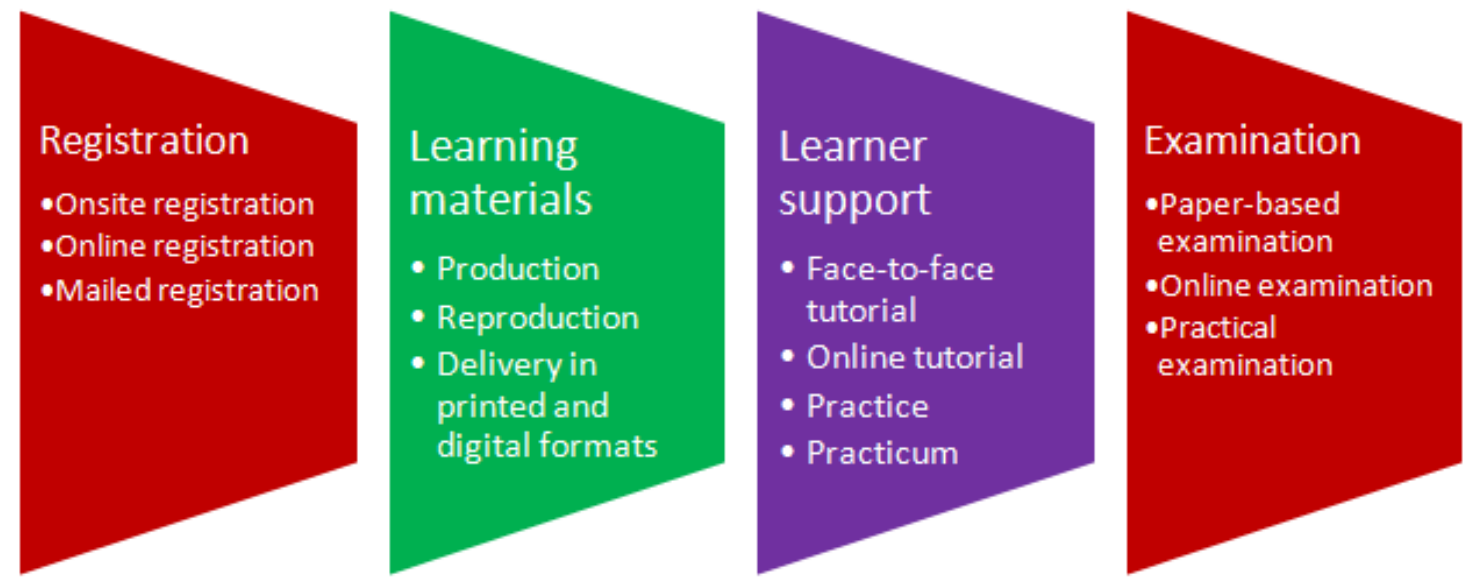

Figure 3. UT QA in operational areas

Figure 4 indicates UT QA in academic areas, which cover core activities on academic content sides of the distance education process. These include curriculum development, learning materials development, learner support, and examination. 


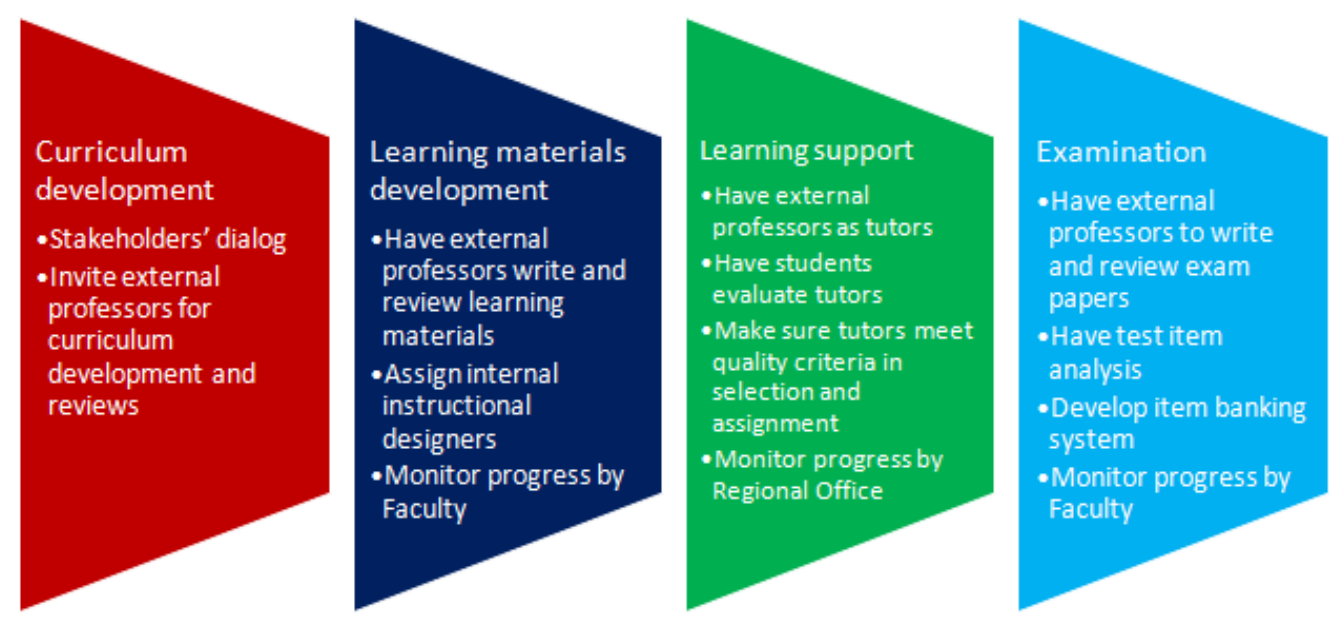

Figure 4. UT QA in academic areas

UT QA system involves external quality reviews and assessment coordinated by the Quality Assurance Center. External quality assessment for ISO is conducted every year for ISO 9001 Quality Management System, ISO 27001 Information Technology Security System, and ANSI for Data Center Management System, with assessment certification performed every three years. Institution and Study Program Accreditation are conducted by the National Board for Higher Education Accreditation every 3 years. Quality Reviews by the International Council for Open and Distance Education (ICDE) are held every 3 years. These external assessment and reviews are aimed at ensuring continuous improvement and meeting high quality criteria and measures of its distance education practice up to the accepted national and international standards.

\section{Reflection on the development and outlook of the open university}

The journey of distance education has lasted for over 200 years since the first mailed lessons was introduced in the USA in 1728, and over 180 years since the first correspondence education introduced in UK by Sir Isaac Pitman Colleges in 1840 (Holmberg, 2008). Often acknowledged as the emergence of distance education in higher education, the University of London External Program began in 1858 (Holmberg, 2008). Table 9 summarizes sketches the milestones in the historical journey of open and distance education worldwide, including some intellectual milestones of the publications in the field of distance education worldwide and in Indonesia.

Table 9. Milestone sketches in the journey of open and distance education

\begin{tabular}{cl}
\hline Year & Milestone journey of open and distance education \\
\hline 1728 & Mailed lessons introduced in Boston, USA (Holmberg, 2008) \\
1840 & Correspondence education introduced in UK by Sir Isaac Pitman Colleges \\
1858 & University of London External Programme \\
1938 & International Council for Correspondence Education (ICCE) established \\
1960 & On the methods of teaching by correspondence by Borje Holmberg \\
1969 & The Open University of the United Kingdom established \\
\hline
\end{tabular}


Table 9. advanced

\begin{tabular}{cl}
\hline Year & Milestone journey of open and distance education \\
\hline 1982 & International Council for Open and Distance Education (ICDE) - new name \\
1984 & Universitas Terbuka established \\
1986 & The Foundations of distance education by Desmond Keegan \\
1987 & Asian Association of Open Universities (AAOU) founded \\
1993 & Pendidikan jarak jauh by Atwi Suparman \\
1995 & Theory and practice of distance education by Borje Holmberg \\
2004 & Theory and practice of online learning by Terry Anderson \& Fathi Elloumi \\
2015 & Teaching in a digital age by Tony Bates \\
2018 & ICDE From correspondence to distance to online by David Sewart \\
2019 & Pembelajaran online by Tian Belawati \\
\hline
\end{tabular}

Although correspondence education was earlier introduced in the $18^{\text {th }}$ century, it was not until the second half of the $20^{\text {th }}$ century that the first theoretical discussion of correspondence education was written (Holmberg, 1960). The development of distance education was further marked by the establishment in 1969 of the first Open University of the United Kingdom based on broadcast media and self-instructional printed learning materials. This was further followed by further establishments of open universities throughout the world. The term distance education has become widely accepted to replace the term correspondence education, and publications in distance education flourished (See: Suparman, 1993; Holmberg, 1995; Keegan 1986).

The introduction of the internet in during last decade of the $20^{\text {th }}$ century has further brought about transformation of distance education integrating online learning (Anderson and Elloumi, 2004. This has then been followed by the digitalization of teaching and learning I higher education (Bates, 2015). The world of distance education has stepped up into the next stage, transforming from correspondence to distance to online learning (Sewart, 2019; Belawati, 2019). In other ways, Bozkurt (2019) summarizes ages and generations of distance education as illustrated in Figure 5.
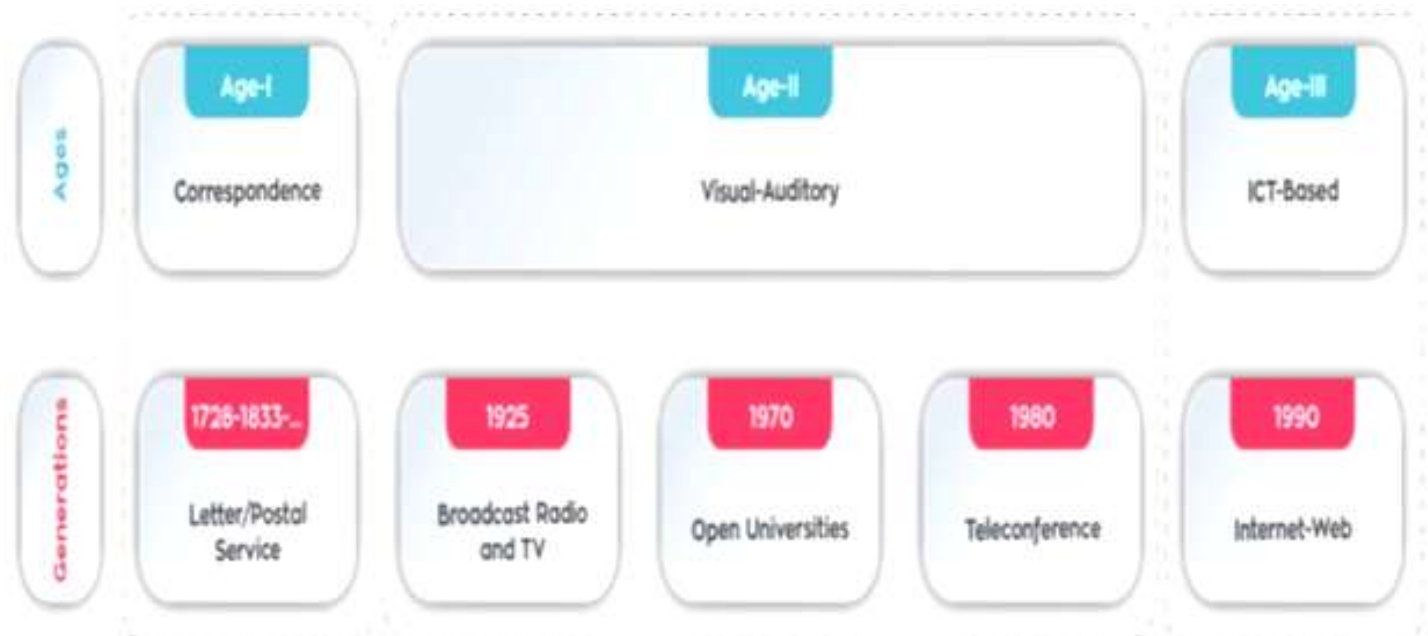

Taken from Bozkurt, 2019, p. 253

Figure 5. Ages and generations of distance education 
The field of educational technology that supports the development of distance education has as well flourished in terms of pedagogical approaches and new terms introduced to describe its innovations using new technology. The development in the field of educational technology during past two decades have been documented by Weller (2018) in Table 10.

Table 10. New Terms Introduced in Educational Technology During The Past Two Decades

\begin{tabular}{ll}
\hline Terms introduced in $\mathbf{1 9 9 8}$ to $\mathbf{2 0 0 7}$ & Terms introduced in2008 to 2017 \\
\hline 1998 Wikis & 2008 E-portfolios \\
1999 E-learning & 2009 Twitter and Social Media \\
2000 Learning Objects & 2010 Connectivism \\
2001 E-learning Standards & 2011 Personal Learning Environments (PLE) \\
2002 Open Educational Resources (OER) & 2012 MOOCs \\
2003 Blogs & 2013 Open Textbooks \\
2004 Learning Management System (LMS) & 2014 Learning Analytics \\
2005 Video & 2015 Digital Badges \\
2006 Web 2.0 & 2016 Return of Artificial Intelligence (Al) \\
2007 Second Life and Virtual Worlds & 2017 Blockchain \\
\hline
\end{tabular}

Taken from: Weller, 2018, pp. 55-69

Open universities around the world have been running for 50 years since the UKOU was established back in 1969, and today some 8 million students enroll in open universities worldwide (Paul and Tait, 2019). There are questions as to whether the open universities are still relevant and how they can excel in the new landscape of higher education in the digital age when all types of higher education institutions and the academia are moving towards online. Paul and Tait (2019) argue that open universities have maintained its strengths in terms of commitment to openness, flexibility, and access; capacity for large-scale provision; support for part-time and working students; and commitment to technology-enhanced learning. Earlier, Tait (2008) also comments that the open universities continue strengthening its sets of functions within the higher education system for capacity building, provision of individual opportunity and social justice, change and renewal, and nation building.

Addressing the digital age, open universities need to maintain and strengthen the advantages of access, cost, and quality in ODL provision (Daniel, 2019). For higher education institutions including open universities, four dimensions of moving knowledge sharing and creation online need to include the values of being accessible, open, communicative ad collaborative, and timely (Zorn, Haywood, and Glachant, 2018). The challenge for open universities is then to make these functions and values materialize effectively to serve the needs of the students and be able to add values in the development of competencies through online learning and teaching environments.

\section{CONCLUSION}

The UT QA system has evolved to integrate new technology into its distance learning system. The UT QA system was initiated with the distance education operational management system and continued to integrate academic processes to assure the quality of its educational services to students. Any QA system involves internal and external reviews and assessment, that are time consuming processes involving all staff and management. Along with the use of new technology in open and distance learning, the UT QA system is also in transformation to integrate audit based 
and analytic based QA system that is expected to be effectively implemented to benefit the continuous improvement processes in all dimensions of its open and distance learning system.

UT has enabled access to quality of higher education to the society coming from various backgrounds and circumstances, irrespective of geographical, work, and socio-cultural obstacles. Stakeholders have high expectations of the roles of UT in national human resource development. As an autonomous state open university, UT has been expected by the former Minister of Research, Technology, and Higher Education to be a pioneer and leading cyber university education in Indonesia. Widening access to quality higher education has been the priority for UT to accommodate more than 2, 3, 5 million students as expected by the formerly Ministry of Research, Technology, and Higher Education. As an open university and experienced online learning university, UT is further expected to have a further role as a modern cyber university able to provide online courses for students from other universities to have online learning experiences (Darojat, 2019).

\section{Acknowledgement}

The idea of writing this paper emerged when I had the opportunity during the second semester of 2019 to take up the Asian Association of Open Universities (AAOU) Exchange Fellowships for one month respectively in three important open universities of Asia, namely the Open University of Sri Lanka (OUSL), National Open University (NOU Taiwan), and University of the Philippines Open University (UPOU). During my Fellowship terms, leaders and colleagues in the three open universities and participating Fellows from other AAOU member institutions asked similar questions on how Universitas Terbuka (UT) operates and how it assures its quality. I thank leaders and colleagues of the AAOU member open universities for the questions and responses to my presentations on UT operations and its quality assurance system during my Fellowship terms, which then become the basis of this paper. I thank the Rector of UT for allowing me to take up the prestigious AAOU Exchange Fellowships, and to my UT colleagues for sharing the joy and spirit of running the operational aspects of the university.

\section{REFERENCES}

Ahmad, I. (2018). Indonesia good practices on QA, recognition and student mobility programs. Presentation by Acting Director General of Learning and Student Affairs, Ministry of Research, Technology, and Higher Education, 4 June 2018.

Alan Tait. (2008). What are open universities for?, Open Learning: The Journal of Open, Distance and e-Learning, 23:2, 85-93, DOI: 10.1080/02680510802051871.

Anderson, T. \& Elloumi, F. (Eds.). (2004). Theory and practice of online learning. Athabasca University, Athabasca.

Bates, A.W. (Tony). (2015). Teaching in a digital age guidelines for designing teaching and learning. Tony Bates Associates Ltd. Vancouver.

Belawati, T. \& Zuhairi. A. (2007). The practice of a quality assurance system in open and distance learning: A case study at Universitas Terbuka Indonesia (The Indonesia Open University). International Review of Research in Open and Distance Learning, Vol 8. No 1.

Belawati, T. (2019). Pembelajaran online, Jakarta, Universitas Terbuka.

Bozkurt, A. (2019). From distance education to open and distance learning: A holistic evaluation of history, definitions, and theories, in Sisman-Ugur, S. and Kurubacak, G. (Eds.). Handbook of Research on Learning in the Age of Transhumanism. IGI Global, Hershey, PA, pp. 252-273. 
Daniel, J. S. (2019). Open Universities: Old concepts and contemporary challenges. The International Review of Research in Open and Distributed Learning, 20(4), pp. 195-211. https://doi.org/10.19173/irrodl.v20i3.4035.

Darojat, O. (2018). How are the results of quality assurance programs used to inform practices at a distance higher education? Turkish Online Journal of Distance Education, Vol. 19, No. 1, pp. 75-88.

Darojat, O. (2019). Lustrum Ke 7 Universitas Terbuka - "Mengukuhkan Konektivitas Bangsa di Era Siber" (The $7^{\text {th }}$ Lustrum of Universitas Terbuka "Strengthening the Nation's Connectivity in Cyber Era"), https://www.youtube.com/watch?v=t88CxQeGGcM on 20 November 2019.

Holmberg, B. (1960). On the methods of teaching by correspondence. Gleerup, Lund.

Holmberg, B. (1995). Theory and practice of distance education. Routledge. New York.

Holmberg, B. (2008). The evolution, principles and practices of distance education. Carl von Ossietzky Universität Oldenburg, Oldenburg.

Keegan, D. (1986). The foundations of distance education. Croom Helm, London.

Logli, C. (2015). Higher education and the public good: Creating inclusive and diverse national universities in Indonesia in the era of globalization, in Neubauer, D. and Collins, C. (Eds), Redefining asia pacific higher education in a global context. Palgrave Macmillan, New York, http://link.springer.com/chapter/10.1057\%2F9781137559203_3.

Logli, C. (2016). Higher education in Indonesia: Contemporary challenges in governance, access, and quality, in Neubauer, D., Hawkins, J., Lee, M. and Collins, C. (Eds), Handbook of asian higher education. Palgrave Macmillan, New York.

Pannen, P. (2018). Higher education systems and institutions, Indonesia, in Shin, J.C. and Teixeira, P. (Eds), Encyclopedia of International Higher Education Systems and Institutions, https://doi.org/10.1007/978-94-017-9553-1_581-1.

Paul, R. \& Tait, A. (2019). Special Issue: Open Universities: Past, Present and Future. International Review of Research in Open and Distributed Learning, 20 (4), i-viii. https://doi.org/10.19173/irrodl.v20i4.4575.

Sewart, D. (2019). Through the mirror of ICDE - from correspondence to distance to online, https://www.icde.org/icde-history-articles/through-the-mirror-of-icde on 28 November 2019.

Suparman, M. A. (1993). Pendidikan Jarak Jauh. Universitas Terbuka, Jakarta.

UGM. (2020). Sejarah Universitas Gajah Mada, https://www.ugm.ac.id/id/aboutUGMPdf/1356sejarah-universitas-gadjah-mada, 20 January 2020.

UT. (2017). Rencana Strategis Bisnis Universitas Terbuka Tahun 2016-2020, Jakarta, Universitas Terbuka unpublished document.

UT. (2019). Katalog Universitas Terbuka 2019. Universitas Terbuka, Jakarta.

UT. (2019a). Laporan Rektor 2018 (Report of Rector 2018). Universitas Terbuka, Jakarta.

Weller, M. (2018). Twenty years of EdTech, in West, R. (Ed.), Foundations of Learning and Instructional Design Technology (1st ed.), available at http://edtechbooks.org/lidtfoundations. [http://edtechbooks.org/-mr].

Zorn, A., Haywood, J., \& Glachant, J. (Eds.). (2018). Higher education in the digital age. Moving academia online. Edward Elgar Publishing, Cheltenham, UK and Northampton, MA, USA. 